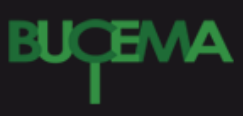

Bulletin du centre d'études médiévales

d'Auxerre | BUCEMA

Hors-série $n^{\circ} 2 \mid 2008$

Le Moyen Âge vu d'ailleurs

\title{
La violencia de los santos en Nueva España
}

\section{Antonio Rubial García}

\section{(2) OpenEdition}

Journals

Edición electrónica

URL: https://journals.openedition.org/cem/4092

DOI: $10.4000 /$ cem.4092

ISSN: 1954-3093

Editor

Centre d'études médiévales Saint-Germain d'Auxerre

Referencia electrónica

Antonio Rubial García, «La violencia de los santos en Nueva España », Bulletin du centre d'études médiévales d'Auxerre | BUCEMA [En ligne], Hors-série n² 2 | 2008, mis en ligne le 23 janvier 2008, consulté le 02 mars 2023. URL : http://journals.openedition.org/cem/4092 ; DOI : https://doi.org/ $10.4000 /$ cem. 4092

Este documento fue generado automáticamente el 2 marzo 2023.

\section{c) (1) (ㅇ)}

Creative Commons - Attribution - Pas d'Utilisation Commerciale - Partage dans les Mêmes Conditions 4.0 International - CC BY-NC-SA 4.0

https://creativecommons.org/licenses/by-nc-sa/4.0/ 


\title{
La violencia de los santos en Nueva España
}

\author{
Antonio Rubial García
}

1 A lo largo de su historia el Cristianismo se ha debatido entre dos concepciones de Dios encontradas y aparentemente contradictorias. Una, que lo ve como una fuerza justiciera y vengadora, la otra que exalta su faceta providencial y amorosa. Quiero desarrollar en mi artículo la recepción que se tuvo de la primera concepción en Nueva España a partir de las representaciones visuales y textuales de los santos, tanto en su papel de víctimas, como de victimarios, sobre todo en relación con el martirio, el ascetismo, la herejía y la idolatría.

2 Mucho se ha escrito sobre los valores cristianos encaminados a exaltar el amor a los semejantes, e incluso a los enemigos, basados en las enseñanzas de Jesús sobre este tema. Sin embargo, son escasos los estudios que abundan sobre la exaltación de la violencia en el cristianismo basada, igualmente, en textos bíblicos, tanto del nuevo como del viejo testamento. Con todo, a lo largo de la Edad Media se habían desarrollado en Europa y en el Cercano Oriente profusamente ambas temáticas ${ }^{1}$.

Los santos como víctimas

3 El primer tipo de violencia aceptado por el cristianismo helenístico, aunque no por las variantes gnósticas, fue el martirio. La entrega voluntaria a la tortura y a la muerte y la aceptación del papel de víctima propiciatoria a partir del modelo de Cristo estuvieron presentes en él desde el siglo I, pero no se consolidaron hasta el siglo IV con la hagiografía promovida por una Iglesia triunfante apoyada por el Estado. Tanto para los hagiógrafos como Eusebio de Cesaréa, como para los teólogos como San Agustín, Dios Padre había aceptado el derramamiento de sangre de su hijo para la redención del pecado original y el de sus seguidores como un medio para la expansión, y el triunfo final, de la religión verdadera. Por otro lado, como señala atinadamente Michael Roberts, las narraciones de mártires son en realidad historias de guerra porque la vida y la muerte de los mártires era un modelo del combate espiritual y del triunfo celestial contra las fuerzas demoníacas ${ }^{2}$. 
4 Durante la Edad Media, sin embargo, el martirio dejó de ser una opción para los cristianos, encerrados en un mundo donde su fe era predominante, y salvo algunos casos en la España califal del siglo X o entre los misioneros mendicantes en el Norte de África en los siglos XII y XIV, la santidad por martirio era sólo un modelo que pertenecía a los orígenes fundacionales del cristianismo. A pesar de ello, a partir del siglo XV la presencia de los mártires se hizo más notable en el arte y en la literatura. El fenómeno tenía que ver con el regreso a los orígenes pues los mártires eran un símbolo de ese cristianismo primitivo al que todos querían volver. La presencia de esta iconografía se acentuó con la Contrarreforma pues esos santos eran los únicos que reconocían incluso los protestantes. Para la reforma católica el tema de los mártires estaba relacionado con la exaltación de la libertad, de la existencia de una fe única e indivisa, de una fe sin dudas, pues el mártir da testimonio de una creencia sin fisuras, absoluta, a la que uno se entrega hasta la muerte. Al final son los que más se asemejaban a Cristo, el primer mártir. Para esta época, la exaltación de los mártires tenía como finalidad excitar los sentimientos de piedad, reforzar la memoria y dirigir a los observadores a abandonar el pecado e impulsar la práctica de las virtudes ${ }^{3}$.

5 En ese ambiente se educaron los evangelizadores que pasaron a América en el siglo XVI, a donde esperaban además encontrar la muerte como los primeros apóstoles. Pero ésta era una tierra ya conquistada por los cristianos y los frailes pudieron imponer la nueva fe con el total apoyo de las armas españolas y sin poner en riesgo sus vidas. Con todo, muy pronto se elaboró una concepción que convertía a la Iglesia indígena fundada por los misioneros en un espejo del cristianismo primitivo apostólico. Dentro de esta construcción se desarrolló la narración del martirio de tres niños indígenas de Tlaxcala, dos de ellos nobles, asesinados por unos idólatras por defender la fe que acababan de recibir ${ }^{4}$. Para los franciscanos, maestros de los pequeños mártires, su muerte era una muestra de los frutos conseguidos por su labor misional y un argumento que confirmaba la pretensión de que la Iglesia novohispana era un espejo fiel de la primera Iglesia apostólica, la de los tiempos de las persecuciones romanas.

6 Sin embargo, estos niños no podían ser venerados pues no estaban canonizados. Era pues necesario importar reliquias y promover las imágenes de los santos cristianos de los tiempos apostólicos. Por ello, desde fechas tempranas, los religiosos trajeron de Europa objetos y restos mortales de los mártires europeos para sacralizar sus templos y los propusieron para ser venerados por los fieles. En 1544 hay noticias de que los dominicos trajeron desde Alemania reliquias de las once mil vírgenes que habían sido arrojadas a las calles por los protestantes. Décadas después, en 1573, fray Alonso de la Veracruz trajo en 1573 un trozo de la cruz de Cristo y otras reliquias de san Pedro y san Pablo ${ }^{5}$. Pero sin duda, quienes se distinguieron más como promotores del culto a las reliquias de mártires fueron los jesuitas. En 1577, a instancias de los miembros de su orden radicados en el nuevo mundo, fueron enviadas desde Roma numerosas reliquias para las iglesias de Nueva España. Para celebrar su llegada en 1578, los jesuitas organizaron, en la fiesta de todos los santos, una apoteósica recepción con arcos, procesiones, certámenes poéticos, pendones, juegos, danzas y con una representación teatral ${ }^{6}$.

7 Junto a este culto a las reliquias, en los murales, portadas, altares y retablos de las iglesias se colocaron imágenes donde se exaltaba la muerte de esos personajes y con lujo de detalle se mostraba su sangre derramada entre los más crueles tormentos. Acuchillados, apedreados, asaeteados, desollados, quemados, mutilados, esos cuerpos 
fueron mostrados a la veneración de todos los grupos de la multiétnica sociedad novohispana. Es difícil determinar el modo como impactaron estos cultos en el ámbito indígena, pero podemos aventurar que esa enorme cantidad de representaciones asociadas con la sangre, incluidas las de Cristo, debieron constituir para los indios un rico arsenal de imágenes que los remitían a la violencia de los tiempos prehispánicos $\mathrm{y}$, sobre todo, a los sacrificios ofrecidos a sus dioses. Santa Catalina de Alejandría con una cabeza a sus pies debió hablarles de los trofeos de guerra que en algunos pueblos los guerreros acostumbraban obtener como parte de su prestigio. El martirio de San Sebastián fue quizás asociado con el sacrificio por asaeteamiento que se realizaba con algunos prisioneros capturados en la guerra, además de ser iconográficamente el más cercano a la crucifixión ${ }^{7}$. El corazón traspasado por tres flechas que simbolizaba a San Agustín debió referirlos a la ceremonia en la que se extraía esa víscera del cuerpo de los sacrificados. La muerte de San Lorenzo, pudo recordarles a las víctimas humanas ofrecidas en honor de la diosa Cihuacóatl. El martirio de San Bartolomé, a quien le fue quitada la piel, pudo recordarles al dios Xipe Totec, señor de las cosechas a quien se ofrecía un sacrificio por desollamiento, después del cual el sacerdote bailaba colocando sobre su cuerpo la piel de la víctima.

8 A menudo, como sucedió en la Baja Edad Media, tormentos muy parecidos a los de los mártires fueron representados en las escenas del infierno, espacio que durante el Barroco se explotó como el más cruel y violento de los mundos. Sin embargo, ya desde el siglo XVI, en el pueblo de Xoxoteco se representó un infierno aterrador y, en una de sus escenas, tres demonios desuellan a una víctima, de la misma manera que lo hacían los sacerdotes del dios Xipe Totec. De hecho sabemos que el frustrado sacrificio de Isaac fue un tema utilizado por los frailes para predicar contra los sacrificios humanos en honor de las divinidades y sin duda estaba lejos de la voluntad de los frailes propiciar tales asociaciones. Para ellos los sacrificios eran una prueba de la presencia demoníaca en América, como se muestra en el códice Florentino, donde se representa un sacrificio por extracción de corazón que se realiza ante un ídolo demonio. Con todo, es muy probable que la violencia cristiana haya hecho más fácil el camino de la conversión.

9 La manera como el lenguaje de violencia cristiano fue asimilado por los indios y el proceso de adaptación que sufrió en todo el ámbito novohispano se puede constatar con innumerables ejemplos. En la zona maya, existen testimonios de la presencia de sacrificios humanos después de la conquista en los que se había integrado la crucifixión como un método sacrificial ${ }^{8}$. En la frontera norte, los indios tepehuanos rebeldes en la misión de Santiago Papasquiaro dieron muerte al jesuita Diego de Orozco haciendo una parodia de la misa, usando palabras en latín y colocando el cuerpo muerto del sacerdote abierto en forma de $\mathrm{cruz}^{9}$. Los indígenas estaban reaccionando ante las imágenes cristianas apropiándose de ellas, manipulándolas y resemantizándolas para afirmar sus propia identidad social y cultural. La nueva semántica transformaba y trasmitía objetos $y$ prácticas dentro de una formidable ofensiva contra los invasores de sus territorios ${ }^{10}$.

10 Con el tiempo, ciertamente, esas imágenes de los mártires tomaron su verdadera dimensión dentro de una religión cristiana cada vez mejor asimilada por todos los grupos. En la era barroca se convirtieron en temas muy gustados sobre todo como apoyo al culto a las reliquias de los mártires que seguían llegando desde Europa para llenar esta tierra de una santidad que aún no le era reconocida. Sin embargo, en las tierras americanas también comenzaron a darse mártires a partir de la segunda mitad del siglo XVI, cuando los misioneros se enfrentaron con los indómitos chichimecas del 
Norte y fueron víctimas de ellos. A lo largo de las tres centurias virreinales, las crónicas religiosas registraron cuarenta y dos franciscanos y a veintiséis jesuitas que perdieron la vida, víctimas de las continuas rebeliones indígenas y de los ataques de los nómadas que llenaron la historia del norte y del sureste de México. Alrededor de ellos y de sus martirios se construyó la historia misionera de algunas regiones, narrada a la manera de los menologios o colecciones de vidas edificantes. Nacía así un modelo hagiográfico propio de Nueva España : el del mártir entre bárbaros ${ }^{11}$.

11 Al nuevo héroe se le mostraba como víctima del Demonio y sus secuaces, los indios bárbaros, infieles o apóstatas. Sin embargo, ya desde principios del siglo XVII podemos notar que la santidad por martirio de tales religiosos era puesta en duda. El argumento teológico que sostenía tal actitud estaba basado en el hecho de que la mayoría de esos religiosos no habían tenido una voluntad explícita de morir por la fe ; las rebeliones los habían sorprendido sin darles la oportunidad de elegir entre salvar su vida o entregarse al martirio. Por otro lado, los misioneros muertos en el norte habían sido asesinados por indios salvajes, personajes que no estaban contemplados por un modelo hagiográfico nacido durante el dominio del Imperio Romano. El mártir debía morir como víctima de un tirano y entre los nómadas este personaje no existía.

12 Es claro, además, que para los novohispanos de la era barroca no era pertinente mostrar a la cristiandad europea que su tierra era aún una zona de gentiles; de todos modos, la sangre de estos mártires estaba ya dando frutos con la conversión masiva de los bárbaros. En cambio, para los intereses criollos funcionaba mejor un modelo de mártir que sí entraba dentro de los esquemas tradicionales y del cual la Nueva España poseía dos ilustres ejemplos : fray Felipe de Jesús y fray Bartolomé Gutiérrez, criollos que habían muerto en el Japón por la fe de Cristo. Japón presentaba las condiciones ideales que llenaban el esquema del martirio: era un país con un emperador y con crueles gobernadores, que cumplían con creces el tipo "romano" del tirano. Por otro lado los misioneros se habían trasladado allá a sabiendas que podían padecer martirio, pues en Japón existía un odio explícito hacia la fe católica y una persecución declarada. Además, al ser Nueva España madre de misioneros y de mártires en Asia, se volvía una nación evangelizadora como lo eran las de Europa, lo que constituía una prueba fehaciente de su madurez espiritual y de su pretensión de ser espejo y sucesora de la Iglesia primitiva apostólica. El presbítero Arias de Villalobos se hacía eco de este sentimiento en un enorme poema sobre la grandeza de la Ciudad de México en el que explicaba cómo una laguna que había recibido la sangre de los sacrificios humanos se había convertido en madre de una ofrenda de mártires que con su sangre fertilizaban la cristiandad en el Japón ${ }^{12}$.

13 A partir de la segunda mitad del siglo XVII, el modelo «japonés», y la necesidad de aproximar a los mártires entre los bárbaros americanos a los héroes del cristianismo primitivo, las descripciones de la vida y la muerte de estos se enriquecieron con elementos nuevos. Por principio de cuentas, el nuevo modelo de mártir novohispano exigía no sólo otro género de bárbaro, sino también un tipo diferente de verdugo y un tratamiento más acabado de las circunstancias del martirio. Frente a la mayor parte de los frailes menores muertos en el siglo XVI, casi todos a manos de infieles y en medio del campo, los jesuitas y franciscanos de las centurias posteriores fueron víctimas de los indios apóstatas, de las rebeliones que destruían iglesias y poblados. Así, los nuevos malvados eran individuos con nombre, hechiceros o gente cercana a la misión como el Nacabeba que intervino en la muerte del jesuita Hernando de Tapia. En un intento de 
adaptarlos al modelo "imperial», el cronista jesuita Andrés Pérez de Ribas nos los muestra en sus conciliábulos, " como en los tribunales romanos » y el franciscano fray Isidro Félix de Espinosa los llama «tiranos » ${ }^{13}$.

14 Para demostrar que los martirios reunían los requisitos solicitados por Roma, los cronistas ponían en labios de los mártires edificantes sermones mientras agonizaban, y hasta construían diálogos entre ellos y sus adversarios. Con esos textos se demostraba, que la causa de su martirio había sido el odio de los apóstatas hacia el evangelio, que ya conocían, y la necesidad de exterminar a los sacerdotes que los conminaban a dejar sus idolatrías, sus borracheras y su afán de tener muchas mujeres. Además, se insistía en que la entrega a la muerte era un acto voluntario ${ }^{14}$. Para reforzar esta postura se hicieron innumerables pinturas siguiendo el modelo iconográfico de los mártires antiguos: se mostraba al personaje portando los símbolos de su martirio, atravesado por las lanzas o siendo devorado por los caníbales. Sobre todo los colegios franciscanos de Propaganda Fide supieron utilizar muy bien estos medios visuales para obtener apoyo de las autoridades para sus misiones. Pero sobre todo fueron los mártires en el Japón, y fray Felipe de Jesús en especial, quienes recibieron una mayor atención pues entre ellos estaba el único beato canonizado que Nueva España había obtenido a lo largo sus tres primeras centurias de cristianismo.

15 En las representaciones del martirio los victimarios siempre aparecían con los rasgos del no cristiano - el japonés o el bárbaro -, con rostros crueles y actitudes de gozo por el dolor ajeno. Sin embargo, esta no era la única violencia ejercida sobre el cuerpo de los santos representada en el ámbito cristiano ; en varias ocasiones el victimario era un ángel del Señor, en otras, el verdugo era al mismo tiempo la víctima.

16 En el primer caso estamos ante una violencia simbólica, una forma de representar la experiencia mística. Quizás el ejemplo más conocido sea el de la transverberación de Santa Teresa de Jesús a quien, según una visión descrita por ella misma, un ángel le atravesó el corazón con la flecha del amor divino, la cual provocó en su pecho una mezcla de dolor y gozo. El tema no era nuevo. Durante la Edad Media se representó a San Agustín como un corazón traspasado por tres flechas, recuerdo de una frase del libro IX de Las Confesiones: "Habías herido mi corazón con las flechas de tu amor ${ }^{15}$. Ambos santos fueron sumamente representados en Nueva España, donde la experiencia mística tenía una rica gama de manifestaciones. San José y la Virgen aparecían también con los corazones traspasados por flechas, simbolizando los dolores que sufrieron como padres del Salvador. Un caso muy significativo al respecto es el del cuadro de Nicolás Rodríguez Juárez que representa la escena del ángel que purifica los labios de Isaías, aunque de hecho le está sacando la lengua con unas tenazas.

17 Con todo, es mucho más común la representación de la violencia ejercida contra el propio cuerpo. Aunque el ascetismo, no es privativo del cristianismo, en éste « se volvió un método de conducta racional tendiente a sobrepasar el estado de la naturaleza [...] al permitir al hombre sustraerse de la potencia de los instintos ${ }^{16} »$. Sin llegar a la mutilación, esta forma de atormentar el propio cuerpo fue justificada ampliamente desde el cristianismo primitivo. Por un lado, someter al cuerpo a golpes y privaciones era un medio de preparación para resistir la tentación ; era así un medio místico para mantenerse en la oración y la contemplación al debilitar el cuerpo, y con ello las pasiones. Por otro lado, era una forma de imitar a Cristo y convertir el propio cuerpo en un espejo del de él, con lo cual se reforzaba la unión amorosa. Por último el autosacrificio constituía una manera de hacer penitencia por los pecados propios y por 
los ajenos, con lo cual se intentaba detener la ira divina. El yo cristiano es un yo pecador cuya finalidad es suprimir el deseo por medio del ascetismo ${ }^{17}$.

18 En la Alta Edad Media, la flagelación fue una importante práctica ascética en los monasterios, se realizaba en privado y era considerada la puerta para las demás virtudes, como la oración, la humildad, la castidad y la templanza. A partir del siglo XIII, como consecuencia de la predicación mendicante, los azotes infringidos al propio cuerpo se hicieron públicos y se extendieron a los laicos y en la Baja Edad Media tuvieron una extraordinaria difusión. En Nueva España, esa forma de violencia contra el propio cuerpo fue inculcada por los misioneros a los miembros de las comunidades indígenas. Algún religioso, como el agustino fray Antonio de Roa, hacía que sus ayudantes lo abofetearan, golpearan, azotaran, escupieran, obligaran a caminar descalzo sobre brasas ardientes y vertieran aceite hirviendo sobre su cuerpo ; todo esto lo hacía en demostración « de todo aquello que les predicaba » sobre los sufrimientos de Cristo ${ }^{18}$. Los indios aceptaron estas prácticas de violencia contra el propio cuerpo en sustitución de otras de autosacrificio muy difundidas en el mundo prehispánico, como la extracción de sangre de diferentes partes del cuerpo como ofrenda a los dioses. Así, dos tradiciones sangrientas se amalgamaron para dar origen a fenómenos de derramamiento colectivo de sangre que tenían como escenario sobre todo las procesiones de Semana Santa.

19 Tales prácticas se veían reforzadas también por la gran cantidad de imágenes que mostraban a los santos realizando estos actos y siendo premiados con ello. Santa Rosa de Lima, después de colgarse de los cabellos durante varias horas, recibía la visita de Jesús. Santo Domingo, después de resistir las tentaciones con crueles torturas contra su propio cuerpo fue alimentado por la Virgen María con su leche. San Nicolás Tolentino recibía la visita de la Virgen al terminar sus crueles flagelaciones. Esta tradición tuvo tal arraigo en México, que aún hoy en día sigue siendo una práctica común, portar haces de espinos sobre los hombros y cactus sobre el pecho durante la Semana Santa o en las peregrinaciones a los santuarios con el fin de solicitar salud o fortuna e inclinar la voluntad de Dios y de los santos.

Los santos como victimarios

20 A diferencia del Islam, el Cristianismo desarrolló tardíamente una teología que justificaba la violencia en defensa o expansión de la fe. La primera guerra que impuso la cristianización como imposición de la conquista fue la que hizo Carlomagno contra los sajones a fines del siglo VIII. A partir de entonces, como lo ha demostrado Jean de Flori, una serie de situaciones fueron conformando una teología de la guerra : primero con las justificaciones alrededor de la tregua de Dios; después proponiendo la veneración a santos guerreros y vengadores; y finalmente forjando la idea de guerra santa con sus dos vertientes, la reconquista en la península ibérica y la cruzada en Tierra Santa ${ }^{19}$. A partir de aquí se justificaron también las hogueras inquisitoriales contra herejes y brujas, las persecuciones contra judíos y homosexuales y, finalmente, la abolición y destrucción sistemática en el territorio europeo y americano de creencias y prácticas asociadas con el Islam, el protestantismo o la idolatría ${ }^{20}$. Es claro que en el desarrollo de estas ideas y prácticas el cristianismo estaba respondiendo a una serie de cambios socioeconómicos y políticos del momento, pero también es verdad que sus teólogos encontraron justificaciones para todos estos actos violentos en la Sagrada Escritura y en la visión mesiánica agustiniana que consideraba como una constante en la historia 
humana la guerra entre la ciudad de los hijos de Dios, el pueblo elegido de la nueva Jerusalén, y la de los seguidores de Satanás, quienes serían finalmente vencidos.

21 Las poblaciones nativas americanas recibieron estos mensajes desde el momento mismo de la conquista española. La violencia generada por ese hecho de armas no facilitaba ciertamente la exaltación de un Dios amoroso, e incluso, cuando los frailes evangelizadores iniciaron la llamada " conquista espiritual », en sus mensajes fueron parte importante los temas sobre la violencia, casi tanto como aquellos relacionados con el amor a los semejantes. En un principio, incluso, los religiosos hicieron uso de sus facultades inquisitoriales para castigar con horca y hoguera a aquellos que después de bautizados seguían idolatrando. Extraña paradoja de una religión que predicaba el amor a los enemigos y que era tan contraria a los sacrificios humanos.

22 El tema de la violencia en América estuvo presente en varias discusiones teológicas del siglo XVI. A este respecto es representativa la disputa que se dio entre el dominico fray Bartolomé de las Casas y el franciscano fray Toribio de Motolinía alrededor de el uso de la fuerza para propiciar la conversión al cristianismo. Mientras el primero sostenía que : «La guerra declarada a los infieles para que reciban la religión cristiana... es una guerra temeraria, injusta, inicua, tiránica ${ }^{21}$. " y pugnaba por métodos pacíficos para la conversión, el segundo expresaba : « Y los que no quisieren oír de grado el evangelio de Jesucristo sea por fuerza. Que aquí tiene lugar aquel proverbio: Mas vale bueno por fuerza que malo por grado ${ }^{22}$. " Aunque sin estar de acuerdo con los excesos cometidos por los conquistadores, el franciscano pensaba, con razón, que los indígenas no se habrían convertido si el cristianismo no hubiese sido precedido por una conquista armada, hecho providencial querido por Dios para salvar de las garras del Demonio a tantas almas. Tiempo después fray Jerónimo de Mendieta, correligionario suyo, equipararía a Hernán Cortés con Moisés, pues al igual que él había liberado a un pueblo (el indígena) de la esclavitud de la idolatría ${ }^{23}$.

23 A esta justificación de la violencia de la conquista se unió la promoción de Santiago, uno de los santos más venerados en España por su asociación con la reconquista y con la expulsión de los musulmanes. Desde los mismos tiempos de la lucha armada, menciona el cronista Bernal Díaz del Castillo, se extendió la noticia de que el apóstol guerrero había sido visto en varias batallas contra los indios blandiendo su espada y dando el triunfo a las huestes españolas ${ }^{24}$.

24 Estos textos tuvieron su expresión plástica en el relieve que decoraba el retablo mayor de la iglesia de Santiago Tlatelolco, templo de gran importancia pues anexo a él funcionaba el colegio que tenían los franciscanos para educar a los jóvenes nobles que colaborarían con ellos en el proceso evangelizador. La representación es sumamente extraña pues el apóstol aparece como un guerrero español, cabalgando sobre un brioso caballo, blandiendo una espada como a menudo se representaba la figura del Matamoros, pero en lugar de los musulmanes sus opositores son los indios. A los pies de este Santiago Mataindios aparece una figura con los brazos y los pies formando una suástica; los cánones simbólicos prehispánicos representaban así a los muertos en batalla. No había lugar a dudas sobre la participación activa del apóstol en la mortandad provocada por la conquista. Esta carga simbólica se actualizaba además en todas las fiestas anuales de los pueblos donde las danzas de moros y cristianos, sustituidas a menudo por danzas de la conquista, siempre iban encabezadas por el apóstol a caballo ${ }^{25}$. 
25 Lo que más sorprende no es el papel protagónico de Santiago en la conquista sino la total aceptación que la imagen del santo guerrero español tuvo entre los indígenas. El nombre de este santo aparece asociado a los mitos fundacionales de muchos pueblos y su veneración estaba muy extendida entre los indios según los cronistas. El hecho es explicable porque en el mundo prehispánico era una práctica generalizada que el pueblo conquistado recibiera a los dioses de los vencedores como símbolo de sometimiento. Los indios aceptaron a los santos como parte de esa imposición, como uno de los elementos que traía consigo el nuevo régimen político, pero también porque la conquista había mostrado que los dioses cristianos, Santiago sobre todo, eran muy poderosos, por lo que convenía tenerlos contentos.

26 Este dios ajeno era aceptado porque podía ser propiciado tanto para pedirle beneficios como para librarse de sus daños. Santiago cabalgando sobre su caballo representaba una fuerza viril y avasalladora, un poderoso señor de los cielos al que los mismos sacerdotes cristianos llamaban « el hijo del trueno ». El caballo - animal que los indios no conocían -, además de velocidad, le daba al nuevo dios un carácter aún más majestuoso y lo asociaba con divinidades antiguas que montaban animales fabulosos. La única diferencia con los tiempos pasados era que los nuevos dominadores tenían una actitud exclusivista y no toleraban la convivencia de sus dioses con los de las religiones antiguas. En los casos de Santiago y de San Miguel el contexto de la conquista se volvía aún más efectivo pues tales santos eran mostrados con el atuendo guerrero de los conquistadores.

27 Los santos, al igual que los demonios, se integraron al mundo religioso indígena como fuerzas cósmicas positivas y negativas cuya lucha violenta hacía posible la existencia y continuidad del universo, aunque sus potencialidades creadoras o destructoras no necesariamente correspondían a los códigos de la cultura occidental. De hecho, la mayoría de los santos tenían no sólo poder para otorgar beneficios, sino también eran seres con un potencial destructivo. El cronista franciscano fray Jerónimo de Mendieta cuenta que al principio de la evangelización los indios llamaban a San Francisco el cruel, pues en su fiesta, el cuatro de Octubre, al final de la época de lluvias, comenzaban las heladas y con ellas se perdían maíz y legumbres ${ }^{26}$. Parecería ajeno a la tradición cristiana que a un santo bondadoso como el Pobre de Asís se le atribuyera tal crueldad, pero los indios no veían a los santos como modelos virtuosos sino como dioses que regenteaban el cosmos y que podían ser benevolentes o, como Santiago, destructores.

28 Con el tiempo, la comunidad indígena organizo toda su vida alrededor de estos dioses tutelares de los pueblos que la nueva religión les había impuesto y los asimiló como propios, tanto así que los convirtió en elementos de resistencia. Es muy significativo que mientras en las rebeliones indígenas del siglo XVI los dioses prehispánicos tenían una fuerte presencia, en las de las centurias siguientes eran Cristo, la Virgen o los santos quienes propiciaban y dirigían la lucha armada contra los españoles. En una rebelión de los indios Acaxee en el norte del territorio entre 1591 y 1601, un shaman, que se hizo pasar por obispo, nombró como sus capitanes a dos indios a quienes llamó Santiago y San Pedro. Ellos y sus seguidores matarían a los españoles que serían cegados y convertidos en vacas y ovejas para que pudieran ser muertos con mayor facilidad ${ }^{27}$.

29 La otra figura que, junto con la de Santiago, tuvo un lugar preeminente tanto en la predicación evangelizadora como en la aceptación indígena fue la de San Miguel. Desde fechas muy tempranas el arcángel guerrero estuvo asociado con la lucha que los frailes 
llevaban a cabo contra la idolatría. La idea de que Satanás había abandonado el viejo continente con el nacimiento de Cristo y se había refugiado en América se demostraba retóricamente con la presencia de serpientes en toda la imaginería de los dioses antiguos y, sobre todo, con prácticas satánicas como los sacrificios humanos y la antropofagia. La narración apocalíptica que mostraba a San Miguel expulsando a Luzbel del cielo tuvo una gran difusión a lo largo del siglo XVI en Nueva España. Demonios animalunos y antropomorfos sometidos al arcángel bombardearon la imaginación de los indios, quienes muy posiblemente veían en la imagen de un ser alado venciendo a otro reptante no una contienda del bien contra el mal, sino, de nuevo, la eterna guerra entre los opuestos, la lucha entre las fuerzas celestes contra las del inframundo, la diaria guerra entre el sol y los dioses nocturnos.

30 La presencia de estos sincretismos, al igual que las supervivencias idolátricas, propició que los sectores eclesiásticos comenzaran a elaborar toda una teología de la idolatría en la que el arcángel San Miguel jugó un papel central ${ }^{28}$. En el mundo de las imágenes, esta posición puede ejemplificarse con un cuadro pintado en la primera mitad del siglo XVII por Luís Juárez en el que se representa a un rubicundo arcángel san Miguel venciendo a un Satanás con facciones indígenas. Con nuestros ojos del siglo XXI la imagen tendría un fuerte contenido racista, pero si la vemos dentro de su contexto representa un discurso contra la idolatría, en un momento en el que se llevaba a cabo una campaña de erradicación, respaldada por tratados como los de Jacinto de la Serna y Hernando Ruíz de Alarcón. Es claro que el cuadro no está intentando representar la lucha narrada en el Apocalipsis, antes de los tiempos en el ámbito celeste previo a la creación del cosmos, sino en una tierra con árboles y montañas. Con ello se hacía referencia a un hecho actual, las guerra cósmica seguía y el Demonio con rasgos indios era un símbolo de la presencia de sus fuerzas en América. El cristianismo novohispano había suplantado al Islam o al Protestantismo de Europa por la Idolatría americana.

31 El arcángel San Miguel y su imagen guerrera tuvo tal presencia en la conciencia novohispana en gestación, que quedó indisolublemente ligado al icono más importante de las identidades indígena y criolla: la Virgen de Guadalupe. Esta presencia se ve desde la primera elaboración alegórica realizada alrededor de la imagen por el clérigo Miguel Sánchez, cuya obra se publicó en 1648. La narración asociaba el Libro XII del Apocalipsis - que describía a una mujer con alas, vestida de sol, coronada de estrellas, con la luna bajo sus pies -, con las apariciones guadalupanas y con los presagios y acciones desarrollados alrededor de la conquista de México. La Virgen morena (una Inmaculada Concepción), como la mujer del Apocalipsis, abría sus alas sobre México, simbolizando al águila, emblema del pueblo mexica. El dragón demoníaco, la idolatría de los antiguos habitantes del Anáhuac, había sido sometido por Hernán Cortés y sus guerreros, émulos de san Miguel y sus ángeles. El Tepeyac, el cerro de las apariciones milagrosas, se volvía el desierto al que voló la mujer preñada vestida de sol, espacio sagrado junto con la isleña ciudad de México, transformada en Patmos y en Jerusalén. Finalmente, San Juan, el evangelista y autor del Apocalipsis, prefiguró a los indios Juan Diego y Juan Bernardino y al obispo fray Juan de Zumárraga, los tres testigos de la milagrosa aparición ${ }^{29}$.

32 La violencia de la conquista se transformaba así, no sólo en un mal necesario, pues con ella se había logrado la conversión y salvación de millones de almas, sino también en una alegoría de la lucha cósmica entre el bien y el mal. Sin embargo, esta no era la primera vez que se hacía tal lectura simbólica; ya los cronistas franciscanos habían 
construido desde el siglo XVI la asociación indisoluble entre idolatría y Demonio y se habían colocado a sí mismos como parte de las huestes angélicas. De hecho, a partir de entonces, todas las batallas y la violencia asociadas con la expansión conquistadora y evangelizadora de los españoles y de sus aliados indígenas fue elaborada simbólicamente en estos términos. Así, alrededor de 1570, en un mural que cubría las paredes del templo del pueblo indígena de Ixmiquilpan, se representó la guerra contra los chichimecas, que por esas fechas se llevaba a cabo en la frontera de Nueva España, como una psicomaquia. Guerreros mexicas, ataviados con sus trajes y armas prehispánicos y portando en sus cintos cabezas cortadas, sometían a los bárbaros semidesnudos armados de arcos y flechas y luchaban contra centauros y dragones demoníacos; águilas y ocelotes representaban la lucha entre las virtudes y los vicios. Los frailes agustinos que administraban la parroquia tenían misiones en la zona fronteriza y quisieron mostrar que en esa guerra los indios aliados estaban del lado del bien, mientras que los chichimecas pertenecían a las fuerzas del mal. A pesar de la presencia de modelos renacentistas en la pintura, no cabe duda que los religiosos dejaron en gran libertad a los pintores indígenas para que plasmaran la violencia de la guerra prehispánica, uno de cuyos rasgos era el tomar como trofeo las cabezas de los vencidos ${ }^{30}$.

33 Casi un siglo y medio después, en 1722, se elaboraba la narración de otra escena de la misma guerra en la que participaron indios cristianos otomíes e idólatras chichimecas. Según el padre fray Francisco Xavier de Santa Gertrudis, quien decía basarse en una narración indígena, durante la batalla entre ambos grupos se apareció Santiago y una cruz en el cielo y ante el prodigio no sólo se convirtieron los bárbaros, sino también se fundó la ciudad de Querétaro. Esta batalla nunca se dio en el siglo XVI, pero su tardía elaboración en los ámbitos indígena y español del XVIII, nos habla de la persistencia de los patrones creados en la primera centuria de la conquista ${ }^{31}$.

34 De manera paralela a este discurso antiidolátrico, asunto propio solamente de las cristiandades americanas y asiáticas, se desarrolló en Nueva España - al igual que en Perú - una beligerante postura contra la herejía. Los orígenes de esta ideología se remontan a fines del siglo XII durante la persecución contra los cátaros y el surgimiento de la tradición inquisitorial católica, pero se reforzó con la extendida persecución contra los criptojudíos en la época de los Reyes Católicos y con la ruptura propiciada por la Reforma protestante, que convirtió a España en la campeona de la ortodoxia durante los Austrias.

35 La América hispánica vivió desde la conquista hasta mediados del siglo XVII el antisemitismo trasladado de la península y en su territorio la Inquisición persiguió y llevó a la hoguera a medio centenar de criptojudíos. Un escritor novohispano, Alonso Alberto de Velasco, al hablar de una imagen milagrosa de Cristo, señalaba que uno de sus prodigios había sido el descubrimiento, en 1641, de las prácticas de un grupo de judíos portugueses que fue llevado a la hoguera ${ }^{32}$. En cambio, la presencia de otros « herejes » fue muy esporádica al otro lado del Atlántico. No obstante América recibió el gran despliegue de propaganda que la católica España esparció en todo su imperio contra la demoníaca pravedad de Lutero, de Calvino o de la pérfida Albión. Con discursos visuales y textuales sumamente violentos, se representaba a esos herejes vencidos bajo las armas de las huestes católicas. El cuadro de Pedro Pablo Rubens que mostraba al carro de la Iglesia aplastando a los ciegos y burros heterodoxos tuvo una gran difusión en toda la América hispánica gracias a los grabados que de él se hicieron. 
Los herejes abatidos por un carro también aparecen representados en alegorías eucarísticas relacionadas con Santo Tomás. El mismo éxito tuvo otra composición anónima que mostraba a la nave de la Iglesia atacada por embarcaciones llenas de herejes. Desde cubierta, los santos fundadores de órdenes religiosas eran representados arrojando flechas y lanzas e hiriendo mortalmente a los enemigos de la fe verdadera, mientras Cristo y María guiaban el barco desde el mástil.

36 Un ejemplo textual de este discurso lo encontramos en una crónica dominica novohispana del siglo XVIII, obra de fray Juan de la Cruz y Moya. Al hablar de Santo Domingo este autor señala : "Admitió compasivo a cien mil herejes, que abjuraron sus errores y reconcilió con la Iglesia dándoles saludable penitencia; pero a más de seiscientos que permanecieron en sus errores pertinaces, sentenció al brasero, donde, hechos infernales mariposas, experimentaron lo severo de mano justiciera [...] Por derecho hereditario goza su religión este celo, e imitando a tan gran padre, sus hijos han sido, son y serán Argos vigilantísimos de la viña de la Iglesia, persiguiendo con su doctrina ortodoxa a las obscenas zorrillas de la herejía que la intenta demoler (aunque en vano) con sus pestilentes dogmas. Conociendo esto, el Pastor Sumo del rebaño católico hizo el oficio de inquisidor casi privativo de la religión predicadora ${ }^{33}$.

37 Estos mensajes tomaron también cuerpo en otra de las más divulgadas representaciones del ámbito imperial español : la apocalíptica Inmaculada Concepción. La Virgen que pisaba la cabeza del dragón se volvió la capitana de las huestes católicas que luchaban contra la herejía. Después de unas décadas de disputas teológicas a principios del siglo XVII, la creencia inmaculista se convirtió en razón de estado, en una imagen que asimilaba a la mujer vestida de sol con la mismísima España, la invencible vencedora de Satanás. Este discurso se volvió más virulento en el siglo XVIII y en numerosas imágenes el monstruo de las siete cabezas tomó los rasgos de la pérfida Albión. En toda la América hispánica comenzaron a representarse en esta centuria santos armados con libros, corazones y espadas que con furia exterminaban a las fuerzas heréticas. En una pintura novohispana de esta época se representa al mínimo y dulce San Francisco hiriendo con una daga el pecho del Anticristo. Esta transformación iconográfica que convertía a santos medievales tradicionalmente pacíficos en violentos guerreros no sólo se estaba dando en América. En la España barroca, se anexaban los atributos guerreros de Santiago a santos como San Isidoro - en la colegiata de León - o san Elías - en el templo de Santa Teresa en Ávila. Resulta paradójico que estos discursos de una violencia triunfalista se dieran cuando el imperio español vivía una clara decadencia política, cuando su economía iba en franco descenso y su presencia en Europa se eclipsaba.

38 La asimilación de discursos violentos en el cristianismo del Antiguo Régimen respondía a una situación política y social y el éxito de su recepción estaba marcado porque manejaba un lenguaje que todos los occidentales comprendían. La violencia formaba parte de la vida cotidiana, la guerra era incuestionable - salvo por un pequeño número de irenistas -, la pena de muerte por razones criminales, políticas o religiosas era vista con buenos ojos, incluso por los teólogos más benevolentes, para no mencionar la violencia laboral, familiar, sexual, estatal o de clase. América, aunque protegida por la pax hispánica que se impuso después de la conquista en todo el territorio, vivía situaciones similares : desde el siglo XVIII las secuelas de las guerras europeas tuvieron sus escenarios en los mares americanos y las horcas y las hogueras de los cristianos sustituyeron a los sacrificios humanos de los prehispánicos. Sus costas eran asoladas 
por ataques piratas y en sus fronteras se seguían librando batallas contra los indios insumisos o rebeldes. En esta violencia de todos los días el discurso cristiano no era altisonante, estaba acorde con los tiempos.

Nosotros no somos ajenos a la violencia, está presente en todos lados, bombardeándonos en los medios masivos y convirtiéndose en algo que ha acabado por formar parte de nuestro paisaje. Sin embargo, la secularización que trajo consigo la modernidad permitió al cristianismo desvincularse de ese discurso y poner en segundo plano a su Dios vengativo y guerrero en beneficio de su Dios providente y amoroso. En este sentido el cristianismo actual salió ganando.

\section{NOTAS}

1. Sólo conozco dos estudios que se dedican al tema general de la violencia en la religión. L. MALDONADO, La violencia de lo sagrado. Crueldad versus oblatividad o el ritual del sacrificio. Salamanca, 1974 y R. GIRARD, La violencia y lo sagrado, trad. J. JORDÁ, Barcelona, 1983.

2. M. ROBERTS, Poetry and the Cult of the Martyrs: The Liber Peristephanon of Prudentius, Ann Arbor, University of Michigan Press, 1993, p. 39-77.

3. No es gratuito que incluso los primeros estudios hagiográficos modernos, los de los bolandistas del siglo XVII, se hicieran alrededor de los mártires.

4. La narración había aparecido por primera vez en la obra de fray Toribio de Motolinía, Historia de los indios de la Nueva España (ed. E. O'GORMAN, México, 1969), escrita a mediados del siglo XVI, pero que se mantuvo inédita hasta el siglo XIX. Sin embargo su difusión quedó asegurada cuando fray Juan de Torquemada la incluyó en su Monarquía indiana, editada por primera vez en 1615. Hay edición actual por Miguel León Portilla (7 vol., México, 1975-1983).

5. A. DÁVILA PADILLA, Historia de la fundación y discurso de la provincia de Santiago de México de la orden de predicadores, México, 1955, p. 161 ; J. DE GRIJALVA, Crónica de la Orden de Nuestro Padre San Agustín en las provincias de Nueva España, edición de Nicolás León, México, 1985.

6. J. SÁNCHEZ BAQUERO, Relación breve del principio y progreso de la provincia de Nueva España de la Compañía de Jesús, México, 1945, p. 114 sqq.

7. P. ESCALANTE, «Cristo, su sangre y los indios. Exploraciones iconográficas sobre el arte mexicano del siglo XVI », in $\mathrm{H}$. VON KÜGELGEN, Herencias indígenas, tradiciones europeas y mirada europea, Frankfurt/Madrid, 2004, p. 71-93.

8. V. REIFLER BRICKER, El Cristo indígena, el Rey nativo. El sustrato histórico de la mitología del ritual de los mayas, México, 1993, p. 45.

9. A. PÉREZ DE RIBAS, Historia de los triunphos de Nuestra Santa Fe entre gentes las más bárbaras y fieras del nuevo Orbe, México, 1992, p. 607.

10. M. AHERN, « Martyrs and Idols : Performing Ritual Warfare on Early Missionary Frontiers in Northwest New Spain ", in S. SCHROEDER and S. POOLE, ed., Society \& Religion in Colonial Mexico, University of New Mexico Press (en prensa). 
11. El único texto moderno que trata de este tema es el de Atanasio G. SARAVIA, Los misioneros muertos en el norte de Nueva España (México, 1943), pero su narración se reduce a describir lo narrado en las crónicas religiosas.

12. «Canto intitulado : Mercurio. Dase razón en él, del estado y grandeza de esta gran ciudad de México Tenochtitlan. Desde su principio, al estado que hoy tiene; con los príncipes que le han gobernado por nuestros reyes ", A. DE VILlalobos, México en 1623, México, Viuda de Ch. Bouret, 1907, p. 251.

13. A. PÉREZ DE RIBAS, Historia de los triunphos..., op. cit., p. 48. I. F. DE ESPINOSA, Crónica apostólica y seráphica de todos los colegios de Propaganda Fide de esta Nueva España, ed. L. GÓMEZ CANEDO, Washington, 1964, lib. V, cap. 50, p. 923 sqq.

14. A. RUBIAL, «El mártir colonial. Evolución de una figura heroica », in Memorias del Coloquio internacional El héroe, entre el mito y la historia, México, 2000, p. 75-87.

15. L. REAU, Iconografía del arte cristiano, trad. M. Alcoba. Barcelona, 1997, t. 3, p. 38.

16. E. PEWZNER, El hombre culpable. La locura y la falta en Occidente, trad. S. VILLASEÑOR, México, 1999, p. 309.

17. C. WALKER BYNUM, Fragmentation and Redemption. Essays on Gender and the Human Body in Medieval Religion, New York, 1992, p. 181 sqq.

18. J. DE GRIJALVA, Crónica de la orden de Nuestro Padre San Agustín en las provincias de la Nueva España, México, 1985, p. 221.

19. J. FLORI, La guerra santa. La formación de la idea de cruzada en el Occidente cristiano, trad.

R. PEINADO, Madrid, 2003.

20. R. I. MOORE, La formación de una sociedad represora, trad. E. GAVILÁN, Barcelona, 1989 (Serie General).

21. Fray BARTOLOMÉ DE LAS CASAS, Del único modo de atraer a todas las gentes a la religión verdadera, ed. A. MIRALLES CARLO, México, 1975.

22. Fray toRIBIO DE MOTOLINIA, Carta al emperador Carlos V. 2 de enero de 1555, in E. O 'GoRMAN, ed., Historia de los Indios de la Nueva España, México, 1969, p. 211.

23. J. DE MENDIETA, Historia eclesiástica indiana, ed. A. RUBIAL, México, 1997, t. 1, p. 306.

24. L. CARDILLAC, Santiago Apóstol. El santo de los dos mundos, Guadalajara/Jalisco, 2002 ;

R. HELIODORO VAlLE, Santiago en América, México, 1946.

25. W. B. TAYLOR, Ministros de lo sagrado. Sacerdotes y feligreses en el México del siglo XVIII, México, 1999, t. 2, p. 402 sqq.

26. J. DE MENDIETA, Historia eclesiástica indiana..., op. cit., lib. III, cap. 56, v. I, p. 502.

27. Testimonio del Capitán Francisco Romero de Arellano en Topia, Nueva Vizcaya, 31 de Diciembre de 1603, en T. NAYLOR and C. POLZER, The Presidio and Militia on the Northern Frontier of New Spain 1570-1700. A Documental History, Tucson, 1986, p. 176-179.

28. E. BÁEZ MACÍAS, El arcángel San Miguel, México, 1979.

29. F. DE LA MAZA, El guadalupanismo mexicano, México, 1981, p. 71.

30. E. I. ESTRADA DE GERLERO, « El friso monumental de Itzmiquilpan », in Actes du XLII Congrès International des Américanistes, Paris, 2-9 Septiembre, 1976. E. WAKE, « Sacred books and sacred songs from former days : Sourcing the mural paintings at San Miguel Arcángel Ixmiquilpan », Estudios de Cultura Nahuatl, 31, 2001, p. 106-140.

31. A. RUBiAl GARCíA, « Santiago y la cruz de piedra. La mítica y milagrosa fundación de Querétaro, una elaboración del Siglo de las Luces? » in R. JIMÉNEZ, ed., Creencias y prácticas religiosas en Querétaro. Siglos XVI-XIX, México, 2004, p. 25-104.

32. A. A. DE VELASCO, Renovación por si misma de la soberana imagen de Cristo Señor Nuestro crucificado que llaman de Itzmiquilpan, México, 1688. 
33. J. DE LA CRUZ Y MOYA, Historia de la Santa y Apostólica Provincia de Santiago de predicadores de México de la Nueva España (1757), México, 1954-1955, t. 1, p. 97.

\section{ÍNDICE}

Mots-clés: saint, violence

Índice geográfico: Nueva España 